\title{
21. CALPIONELLIDS AND THE JURASSIC/CRETACEOUS BOUNDARY AT DEEP SEA DRILLING PROJECT SITE 534, WESTERN NORTH ATLANTIC OCEAN1
}

\author{
Jürgen Remane, Université de Neuchâtel, Institut de Géologie, 11, rue Emile-Argand, \\ CH 2000 Neuchâtel 7, Switzerland
}

\begin{abstract}
Calpionellids occur from Section 534A-87-2 in the lowermost Blake-Bahama Formation down to Section 534A-93-4 in the uppermost Cat Gap Formation. Stratigraphically significant faunas have only been observed between Sections 534A-90-2 and 534A-93-1, indicating calpionellid Zone B (latest Tithonian to earliest Berriasian) for the interval from Sections 534A-90-2 through 534A-92-2 and Zone A (early late Tithonian) for the interval from Sections 534A-92-6 through 534A-93-1. In southeastern France, the Jurassic/Cretaceous boundary, as defined by ammonites, lies in the middle of Zone B. In Hole 534A, the boundary can be placed in the lower half of Core 90.

A strange fact, which cannot yet be explained in a satisfactory manner, is the complete absence of mid-Berriasian through early Valanginian calpionellid associations (Zones C, D, and E), not only at this site, but apparently over most of the western North Atlantic.
\end{abstract}

\section{INTRODUCTION}

Initially, 72 samples from Hole 534A were placed at my disposal for a shore-based study of calpionellid faunas. The result was surprising, inasmuch as no calpionellids were observed in Berriasian through early Valanginian pelagic radiolarian micrites of the Blake-Bahama Formation. As a matter of fact, only calpionellid Zone B (latest Tithonian to earliest Berriasian) could at first be determined, leaving another gap in the early late Tithonian (Zone A).

Fortunately, I had the opportunity to participate in the postcruise meeting at Lamont-Doherty Geological Observatory where I was able to study the shipboard collection of thin sections and select 32 further samples within the critical interval from Cores 81 to 95 . Discussion with Peter H. Roth and Dan Habib confirmed that the Berriasian to early Valanginian are positively documented by nannofossils and palynomorphs. Therefore, the absence of calpionellids belonging to this interval cannot be attributed to a stratigraphic gap.

Most of the samples were more or less suitable for cutting thin sections, and a total of 101 samples was studied under the microscope, using 162 thin sections. These samples bridge the interval from Sections 534A58-4 to 534A-102-3. Details of their stratigraphical distribution are presented in Table 1. It should be pointed out, however, that sampling concentrated on the most indurated portions of the cores, that is, the most calcareous parts of the succession. Inevitably, observations concerning microfacies and sedimentary environments are biased in this sense.

From Section 534A-64-2 (Blake-Bahama Formation) down to Section 534A-96-2 (Cat Gap Formation), radiolarian-bearing pelagic micrites are absolutely dominant. Radiolarians are mostly calcified and may be-

\footnotetext{
${ }^{1}$ Sheridan, R. E., Gradstein, F. M., et al., Init. Repts. DSDP, 76: Washington (U.S. Govt. Printing Office).
}

come very abundant at certain levels (Plate 1, Figs. 1, 2 ). It is just in this kind of microfacies that calpionellids are frequent in the Mediterranean realm. In Hole 534A, however, calpionellids are confined to the interval from Section 534A-87-2 to Section 534A-93-4 (1296.9-1359.9 $\mathrm{m}$ sub-bottom depth). The two uppermost occurrences are stratigraphically isolated (Sections 534A-87-2 and -3 ) and a continuous documentation begins only $10 \mathrm{~m}$ farther down (Core 88, Section 2). According to biostratigraphic data derived from other fossil groups, the calpionellid-bearing interval should have been deposited in the late Tithonian to early Berriasian.

\section{OBSERVED CALPIONELLID SPECIES AND THEIR STRATIGRAPHIC VALUE}

The stratigraphic range of individual calpionellid species as observed in Hole 534A is shown in Figure 1. Within the most critical interval, thin sections were scanned systematically line by line under the microscope in order to obtain a complete record of all species and their relative frequencies. The following species were observed:

1) Calpionella alpina Lorenz (Plate 1, Figs. 3-7) occurs from Sample 88-2, 148-150 cm down to Sample 534A-93-1, 129-130 cm, (from 1307.0 to $1350.3 \mathrm{~m}$ subbottom depth). In the Mediterranean realm C. alpina ranges from early Late Tithonian (calpionellid Subzone $\mathrm{A}_{2}$ ) up to the Berriasian/Valanginian boundary. The extinction is, of course, gradual but well documented from sections in southeastern France dated in detail by ammonites (Busnardo et al., 1979). During this time interval, C. alpina undergoes significant evolutionary changes leading from (1) large, somewhat elongated forms, to (2) a smaller, spherical variety, and then to (3) even smaller, again more elongated forms (Remane, 1963, 1964, 1971; Le Hégarat and Remane, 1968). The first form is characteristic of Zone A (early late Tithonian), whereas the transition from the second to the third variety occurs within Zone B, near the Tithonian/ 
Table 1. Stratigraphic distribution of samples from Hole 534A, studied in thin sections for calpionelids.

\begin{tabular}{|c|c|}
\hline $\begin{array}{c}\text { Sample } \\
\text { (core-section, } \\
\text { interval in } \mathrm{cm} \text { ) }\end{array}$ & $\begin{array}{c}\text { Sample } \\
\text { (core-section, } \\
\text { interval in } \mathrm{cm} \text { ) }\end{array}$ \\
\hline \multicolumn{2}{|c|}{$\begin{array}{l}\text { Blake-Bahama Formation, lower } \\
\text { part (uppermost Tithonian- } \\
\text { Hauterivian) }\end{array}$} \\
\hline $58-4,89-90$ & $81-2,141-143$ \\
\hline $59-1,19-20$ & $81-4,57-58$ \\
\hline $60-2,84-85$ & $82-1,118-119$ \\
\hline $61-5,17-19$ & $82-2,25-27$ \\
\hline $62-1,44-46$ & $82-2,39-40$ \\
\hline $63-1,115-116$ & $84-3,0-2$ \\
\hline $64-2,121-123$ & $84-3,127-129$ \\
\hline $65-1,133-136$ & $84-4,51-53$ \\
\hline $66-2,60-61$ & $84-6,144-146$ \\
\hline $67-4,14-16$ & $85-1,4-6$ \\
\hline $68-3,67-68$ & $85-3,20-22$ \\
\hline $69-2,48-50$ & $85-4,18-19$ \\
\hline $69-4,95-96$ & $85-5,144-146$ \\
\hline $70-2,86-87$ & $86-1,107-109$ \\
\hline $70-3,68-69$ & $86-4,114-115$ \\
\hline $71-1,38-40$ & $86-5,31-33$ \\
\hline $71-3,109-110$ & $87-2,36-37$ \\
\hline $72-2,18-20$ & $87-2,86-88$ \\
\hline $72-5,33-35$ & $87-3,118-119$ \\
\hline $73-1,43-45$ & $87-6,3-4$ \\
\hline $73-4,44-45$ & $88-2,148-150$ \\
\hline $74-3,83-85$ & $88-3,21-22$ \\
\hline $74-4,19-20$ & $88-5,58-60$ \\
\hline $75-1,49-50$ & $89-1,42-43$ \\
\hline $75-3,82-83$ & $89-3,64-66$ \\
\hline $76-3,15-16$ & $89-5,136-138$ \\
\hline $77-2,7-9$ & $90-1,70-72$ \\
\hline $78-1,91-93$ & $90-2,36-38$ \\
\hline $78-2,25-27$ & $90-3,83-85$ \\
\hline $79-3,40-41$ & $90-4,19-20$ \\
\hline $79-6,63-64$ & $91-1,112-114$ \\
\hline $80-1,5-6$ & $91-2,88-90$ \\
\hline $80-5,78-79$ & $91-3,111-113$ \\
\hline $81-2,47-48$ & $91-5,56-58$ \\
\hline \multicolumn{2}{|c|}{$\begin{array}{l}\text { Cat Gap Formation, upper part } \\
\text { (Oxfordian-Tithonian) }\end{array}$} \\
\hline $92-1,80-82$ & $93-3,87-89$ \\
\hline $92-1,82-84$ & $93-4,44-45$ \\
\hline $92-2,11-12$ & $94-3,22-24$ \\
\hline $92-2,70-72$ & $94-4,45-47$ \\
\hline $92-2,99-101$ & $94-4,73-75$ \\
\hline $92-4,80-82$ & $95-2,2-4$ \\
\hline $92-4,86-88$ & $95-2,25-27$ \\
\hline $92-4,91-93$ & $95-3,43-45$ \\
\hline $92-5,28-30$ & $95-3,81-83$ \\
\hline $92-5,84-86$ & $95-3,92-94$ \\
\hline $92-6,30-32$ & $96-1,73-74$ \\
\hline $92-6,50-52$ & $96-2,0-2$ \\
\hline $93-1,112-113$ & $96-3,73-75$ \\
\hline $93-1,129-130$ & $96-5,35-37$ \\
\hline $93-2,59-61$ & $99-1,34-36$ \\
\hline \multirow[t]{2}{*}{$93-2,112-113$} & $100-2,11-12$ \\
\hline & $102-3,79-80$ \\
\hline
\end{tabular}

Berriasian boundary. About 10 longitudinal sections are necessary to determine the "evolutionary level" of $C$. alpina. In material from Hole 534A, only the first two stages of the evolution are clearly represented, and the highest associations show just the transition to the third form. For strata up to Sample 534A-90-2, 36-38 cm $(1323.9 \mathrm{~m})$ an age younger than earliest Berriasian is therefore highly improbable. The large variety of early late Tithonian (Zone A) has been observed in Samples 534A-92-6, 50-52 $\mathrm{cm}$ and 534A-93-1, 129-130 cm (1347.9-1350.3 m).

2) Tintinnopsella carpathica (Murgeanu and Filipescu) (Plate 1, Figs. 8-9) occurs from Sample 534A-90-2, $36-38 \mathrm{~cm}$ down to Sample 534A-93-1, $129-130 \mathrm{~cm}$ (from 1323.9 to $1350.3 \mathrm{~m}$ ). The lowest occurrence is, however, an isolated one, and only between 1323.9 and $1342.5 \mathrm{~m}$ (to Sample 534A-92-2, 99-101 cm) is T. carpathica constantly present, although very rare.

In the Mediterranean realm, the range of $T$. carpathica equals that of the whole family Calpionellidae, from early late Tithonian through early Valanginian (Remane, 1963, 1964; Busnardo et al., 1979). Again, significant evolutionary changes within this time interval allow a finer subdivision. Thus the two specimens from Sample 534A-93-1, 129-130 cm belong to the initial smallest variety, limited to the lower part of Zone A. In the main interval just mentioned (Sections 534A-90-2 to 534A-92-2), somewhat larger specimens were encountered (Plate 1, Figs. 8-9), but we still deal with a relatively small form, which is the only representative of $T$. carpathica within Zone B. The typical large forms, which appear at the base of Zone C, are not represented among materials from Hole 534A. In southeast France, the base of Zone $\mathrm{C}$ coincides with the base of the midBerriasian Berriasiella privasensis Subzone (Zone of Tirnovella occitanica). The forms of T. carpathica thus confirm the results obtained from the morphological study of $C$. alpina, where forms younger than earliest Berriasian are missing, too.

3) Crassicollaria sp. Slightly oblique sections of different species of the genus Crassicollaria are difficult to distinguish. In statistical evaluations of relative frequencies, questionable specific attributions should be avoided. It is nevertheless interesting to control the abundance of these forms, in order to obtain correct values for the relative frequency of Calpionella alpina in Zone A; hence all sections of doubtful specific but certain generic attribution are taken together under the heading "Crassicollaria sp." (see Fig. 1).

4) Crassicollaria parvula Remane (Plate 1, Fig. 10) is even rarer than Tintinnopsella carpathica and occurs sporadically from Sample 534A-90-4, 19-20 cm (at $1326.7 \mathrm{~m}$ ) to Sample 534A-93-3, 87-89 cm (at 1352.9 $\mathrm{m})$. In the Mediterranean realm, this species ranges from early late Tithonian (Zone A) through Early Berriasian, disappearing in Zone C. Although not a very good marker, it is interesting in the present context because it forms a very characteristic association with $\mathrm{Cal}$ pionella alpina and Tintinnopsella carpathica in Zone $\mathrm{B}$, that is, close to the Jurassic/Cretaceous boundary.

5) Crassicollaria intermedia (Durand Delga) (Plate 1, Figs. 11-12) has been observed, in three specimens only, in Core 93, Section 1 at 112 to $113 \mathrm{~cm}$ and at 129 to 130 $\mathrm{cm}$ (i.e., around $1350.2 \mathrm{~m}$ ). In the Mediterranean realm this species is a very good marker, being confined to calpionellid Zone A (early late Tithonian). 


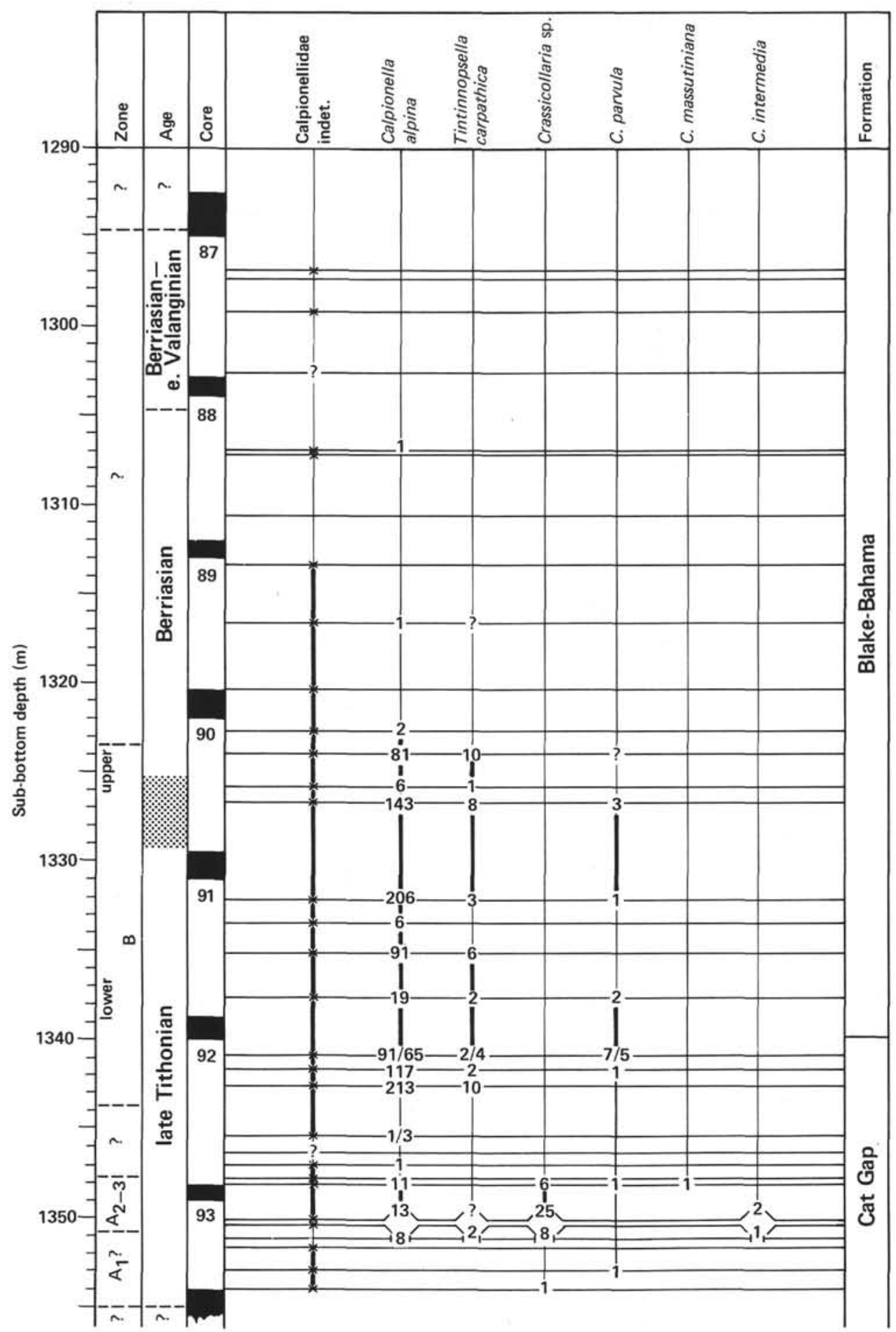

Figure 1. Stratigraphic distribution of calpionellids in Hole 534A. ("Calpionellidae indet." corresponds to indeterminable transverse sections. The number of individuals taxonomically identified is indicated at the level of the respective samples in order to give an idea of the reliability of stratigraphic interpretations. These numbers are not, however, directly related to absolute frequencies. At the top of Core 92, the results from two samples, too close to each other to be separated in the drawing, are given at the same level.)

6) Crassicollaria massutiniana (Colom) One single specimen was encountered in Sample 534A-92-6, 50-52 $\mathrm{cm}($ at $1348.0 \mathrm{~m})$. Like $C$. intermedia, this species is confined to Zone A. Together with C. intermedia, it clearly indicates the presence of early late Tithonian calpionellid associations at Site 534 .

\section{OUANTITATIVE ANALYSIS OF CALPIONELLID ASSOCIATIONS}

As stated earlier, calpionellids occur mainly from Core 88, Section 2 down to Core 93, Section 4, but in most samples they are very rare. Practically no determin- 
able longitudinal sections could be found in the upper portion down to Sample 534A-90-1, 70-72 cm, from Sample 534A-92-4, 80-82 cm to Sample 534A-92-6, 30$32 \mathrm{~cm}$, and below Section 534A-93-1, even though two to four thin sections per sample were scanned systematically. At two levels (Samples 534A-92-5, 28-30 cm and 534A-93-2, 59-61 cm) calpionellids are even completely absent.

Frequencies comparable to those commonly observed in southeastern France are attained only in two limited intervals: from Samples 534A-90-4, 19-20 cm to 534A91-1, 112-114 cm, and from Samples 534A-92-1, 80-82 $\mathrm{cm}$ to 534A-92-2, 99-101 cm. From these associations, statistically significant relative frequencies of species can be calculated, and it appears that Calpionella alpina is always largely predominant (more than $90 \%$ of the fauna!), accompanied by rare Tintinnopsella carpathica and Crassicollaria parvula. This percentage corresponds exactly to the proportion typical for calpionellid Zone B in the Mediterranean realm (Remane 1963, 1964; Barthel et al., 1966). Somewhat poorer faunas between these two abundance maxima and another higher up, in Sample 534A-90-2, 36-38 cm, show a very similar distribution. If we consider both the quantitative data and the morphological arguments previously discussed, it is possible to assign the interval from Sample 534A-90-2, $36-38 \mathrm{~cm}$ (at $1323.9 \mathrm{~m}$ sub-bottom) to Sample 534A92-2, 99-101 cm (at $1342.5 \mathrm{~m}$ ) to calpionellid Zone B with absolute certainty. A third abundance maximum is observed from Sample 534A-92-6, 50-52 cm to 534A$93-1,129-130 \mathrm{~cm}$, but it is far less prominent, and associations of only 18 to 40 determinable sections have been obtained from two to five thin sections per sample, not enough to calculate relative frequencies. There can be no doubt, however, that Calpionella alpina is distinctly less abundant relatively (see Fig. 1) than in Zone B. In this same interval, moreover, the large variety of C. alpina has been observed and Crassicollaria intermedia and Crassicollaria massutiniana have been found. In other words, the interval from Sample 534A-92-6, $50-52 \mathrm{~cm}$ (1348.0 m sub-bottom) to Sample 534A-93-1, $129-130 \mathrm{~cm}(1350.3 \mathrm{~m})$ can be confidently assigned to calpionellid Zone A, Subzone $\mathrm{A}_{2}$ or $\mathrm{A}_{3}$. $\mathrm{A}_{1}$ can be excluded because of the presence of $C$. alpina, but a distinction between $A_{2}$ and $A_{3}$ is impossible on the basis of available quantitative data.

These observations, although somewhat fragmentary, show clearly that the succession of calpionellid species and associations at Site 534 fits well into the western Mediterranean standard zonation (Allemann et al., 1971). But even more important is the fact that in the subbetic structural zone of southern Spain (Barthel et al., 1966; Allemann et al., 1975; Enay and Geyssant, 1975) and in southeastern France (Le Hégarat and Remane 1968, Busnardo et al., 1979), calpionellid and ammonite zones have been correlated in detail, using samples collected bed by bed from the same sections. Time units defined by ammonites can therefore be determined by calpionellids with high precision. The interval belonging to calpionellid Zone $\mathrm{A}$ is thus definitely upper Tithonian, and the Tithonian/Berriasian boundary (i.e, the Jurassic/Cretaceous boundary) can be placed with certainty between Samples 534A-90-2, 36-38 cm and 534A-91-1, 112-114 cm, as in the upper sample the transition to the smallest variety of $C$. alpina indicates basal Berriasian (upper part of Zone B).

\section{GENERAL STRATIGRAPHIC RESULTS}

Starting from the two associations indicating calpionellid Zones A and B, the rest of the succession under question can be dated more or less approximately, and the following stratigraphic divisions can be distinguished (Fig. 1):

\section{(1) Samples 534A-87-2, 36-37 cm (1296.9 m) to 534A-87-6, 3-4 cm (1302.5 m)}

No specifically or generically determinable calpionellids. In the present context, extremely poor associations of this type can only be placed somewhere in the Berriasian through early Valanginian interval, the upper limit being given by the last calpionellids and the lower by the presence of earliest Berriasian associations in Sample 534A-90-2, 36-38 cm.

(2) Samples 534A-88-2, 148-150 cm (1307.0 m) to 534A-90-1, 70-72 cm (1322.7 m)

Isolated Calpionella alpina occur; no zonal attribution is possible, and we are left with the range of C. alpi$n a$ that here indicates the Berriasian, the upper limit being determined by the extinction of $C$. alpina near the Berriasian/Valanginian boundary, the lower by the presence of earliest Berriasian (Zone B) just below.

(3) Samples 534A-90-2, 36-38 cm (1323.9 m) to 534A-92-2, 99-101 cm (1342.5 m) ed).

Calpionellid Zone B (see the description just present-

(4) Samples 534A-92-4, 91-93 cm (1345.3 m) to 534A-92-6, 30-32 cm (1347.8 m)

No characteristic association is present, but the age is given as late Tithonian (upper Zone A to lower Zone B) by associations belonging to Zone $\mathrm{B}$ above and to Zone A below.

\section{(5) Samples 534A-92-6, 50-52 $\mathrm{cm}(1348.0 \mathrm{~m})$ to 534A-93-4, 44-45 cm (1353.9 m)}

A stratigraphically significant association could only be observed in the upper part of this interval (Zone A, see description just presented), but, as the base of Zone A is defined by the appearance of calpionellids, it can be extended here to their lowest occurrence. The whole interval is therefore certainly of the late Tithonian.

In summary, calpionellid Zones A and B are documented beyond any doubt, but neither their upper nor their lower boundaries can be determined precisely, as calpionellids are too rare in critical intervals. There is no positive evidence for the presence of the basal Subzone of $\mathrm{A}\left(\mathrm{A}_{1}\right)$.

It is also interesting that the genus Chitinoidella, which normally precedes calpionellids, could not be discovered in Hole 534A. The typical early Tithonian Saccocoma facies seems also to be missing. 


\section{GAPS IN THE CALPIONELLID SUCCESSION}

From the biostratigraphic account just presented, certain gaps in the documentation of Tithonian faunas become evident. But much more striking is the complete absence of typically Early Cretaceous calpionellids; there is no hint of calpionellid Zones $\mathrm{C}$ through $\mathrm{E}$ corresponding to most of the Berriasian and early Valanginian.

On the other hand, both the early Berriasian Nannoconus colomi Zone and the late Berriasian-early Valanginian Retecapsa neocomica Zone are present in the nannofossil record (Roth, this volume). Palynomorph biostratigraphy points in the same direction: early to middle Valanginian, late Berriasian, and early Berriasian could be separated (Habib, this volume). Under these circumstances, the absence of Early Cretaceous calpionellid associations cannot be due to a stratigraphic gap.

Logically, Zones $\mathrm{C}$ to $\mathrm{E}$ should have shown up in the interval from Cores 87 to 77 or perhaps 75 . Microfacies are constantly favorable for calpionellids (pelagic micrites with calcified radiolarians, Plate 1, Figs. 1-2), and there is no significant difference from strata where calpionellids do occur. In the thin sections studied, it is even impossible to distinguish between the Blake-Baha$\mathrm{ma}$ and the Cat Gap formations. Thus the premature disappearance of calpionellids at Site 534 cannot be explained by a facies change either.

It is also impossible to rely on paleobiogeographic arguments; the complete succession of calpionellids is known from Mexico (Trejo, 1976, 1980) and Cuba (Pop, 1976) where Chitinoidella also is represented by several species. Thus we are left with two alternative hypotheses: either postmortem dissolution of calpionellid loricae (tests) resulting from CCD changes or paleoclimatic factors (e.g., variations of water temperature).

In contrast to the opinion of Remane $(1963,1964)$, calpionellid loricae were primarily calcitic and not aragonitic (Aubry et al., 1975). The original thickness of the lorica wall remains unknown, however, as diagenetic thickening is very frequent (Remane, 1963, 1964). Such thickening can even be observed in Hole 534A (especially Plate 1, Figs. 3, 5, 7, 8), but at certain other levels, calpionellid shells become extremely thin and their outline appears somewhat blurred, observations supporting the theory of postmortem corrosion. The Purbeckian regression at the Jurassic/Cretaceous boundary might have depressed the CCD, thus preserving only latest Tithonian calpionellid faunas.

On the other hand, there seem to be important-and real-variations of calpionellid frequencies, favoring the paleoclimatic hypothesis. The Purbeckian regression might also have blocked off cold currents from entering the early Atlantic, thus allowing an expansion of warmwater calpionellids during the late Tithonian.

If we consider earlier records of calpionellids from the western North Atlantic, the absence of Early Cretaceous calpionellids seems to be rather common. Site $391,22 \mathrm{~km}$ southeast of Site 534, seems not to have been analyzed systematically for calpionellids, but two thin sections, from Cores $391-45$ and $391-46$, studied by the present author (Jansa et al., 1980), yielded only faunas of calpionellid Zone B. In Lehmann's (1972) very detailed account of Site 105, far-reaching analogies with Site 534 appear: radiolarians are constantly present, but determinable calpionellids were only observed in Sample 105-33-1, 42-43 cm, with predominating Calpionella alpina and small Tintinnopsella carpathica, that is, Zone B. A reinvestigation of Sample 105-33-1, 81-83 cm (Jansa et al., 1980) confirmed Lehmann's results. The only difference is the presence of a typical Saccocoma facies at Sites 105 and 100 (Lehmann, 1972).

So far, the only Lower Cretaceous calpionellids known from the western North Atlantic have been figured from Site 100 by Luterbacher (1972). The material stems from washed residues in which calpionellids are very difficult to determine, and Remaniella cadischiana seems to be the only determination that can be maintained. This species ranges from basal Berriasian to early Valanginian.

The problem of gaps in the stratigraphic distribution of calpionellids remains unresolved. A reinvestigation of all Atlantic sites where calpionellids might be found is now in course and will perhaps answer some of these questions.

\section{ACKNOWLEDGMENTS}

I am greatly indebted to the Deep Sea Drilling Project for the opportunity to study this interesting material. In view of the problems that arose in studying the first series of samples, it was vitally important for me to take part in the postcruise meeting at Lamont in July, 1981 , in order to examine the cores, to select additional samples, and to discuss biostratigraphic problems with members of the shipboard party. I am greatly indebted to the Schweizerische Naturforschende Gesellschaft for financial support for this voyage, which otherwise would have been impossible for me.

My sincere thanks go also to Prof. M. Durand Delga, Université de Toulouse, and Dr. R. Lehmann, Esso EPR-E, Bègles, Frances, for critical reading of the manuscript and their helpful suggestions. In addition, I am very grateful to Prof. J. Rodgers, Yale University, for the revision of the English and the fruitful discussion of this text.

\section{REFERENCES}

Allemann, F., Catalano, R., Fares, F., and Remane, J., 1971. Standard calpionellid zonation (upper Tithonian-Valanginian) of the western Mediterranean Province. Proc. II Plankt. Conf. Roma 1970, Vol. 2:1337-1340.

Allemann, F., Grün, W., and Wiedmann, J., 1975. The Berriasian of Caravaca (Prov. of Murcia) in the subbetic zone of Spain and its importance for defining this stage and the Jurassic/Cretaceous boundary. Mem. Bur. Rech. Geol. Min. Fr., (Coll. Limite Jurass.Crétacé, Lyon-Neuchâtel 1973), 86:14-22.

Aubry, M.-P., Bignot, G., Bismuth, H., and Remane, J., 1975. Premiers résultats de l'observation au M.E.B. de la lorica des calpionelles et de quelques microfossiles qui leur sont associés. Rev. Micropaleontol., 18(3):127-133.

Barthel, K. W., Cediel, F., Geyer, O. F., and Remane, J., 1966. Der subbetische Jura von Cehegín (Provinz Murcia, Spanien). Mitt. Bayer. Staatssamml. Palaontol. Hist. Geol., 6:167-211.

Busnardo, R., Thieuloy, J.-P., Moullade, M., 1979. Hypostrato-type mésogéen de l'étage valanginien (sud-est de la France). Ed. Cent. Nat. Rech. Sci., Les stratotypes français (Vol. 6).

Enay, R., and Geyssant, F., 1975. Faunes tithoniques des chaînes bétiques (Espagne méridionale). Mém. Bur. Rech. Geol. Min. Fr., (Coll. Limite Jurass.-Crétacé, Lyon-Neuchâtel 1973), 86:39-55.

Jansa, L. F., Remane, J., and Ascoli, F, 1980. Calpionellid and foraminiferal-ostracode biostratigraphy at the Jurassic/Cretaceous boundary, offshore Eastern Canada. Riv. Ital. Paleontol., 86(1): $67-126$. 
Le Hégarat, G., and Remane, J., 1968. Tithonique supérieur et Berriasien de la bordure cévenole. Corrélation des ammonites et des calpionelles. Geobios, 1:7-70.

Lehmann, R., 1972. Microfossils in thin sections from the Mesozoic deposits of Leg 11, Deep Sea Drilling Project. In Hollister, C. D., Ewing, J. I., et al., Init. Repts. DSDP, 11: Washington (U.S. Govt. Printing Office), 659-663.

Luterbacher, H., 1972. Foraminifera from the Lower Cretaceous and Upper Jurassic of the Northwestern Atlantic. Preliminary note. In Hollister, C. D., Ewing, J. I., et al., Init. Repts. DSDP, 11: Washington (U.S. Govt. Printing Office), 561-593.

Pop, G., 1976. Tithonian-Valanginian calpionellid zones from Cuba. Dari Seama Sedintelor., 62(1974-1975):237-266.
Remane, J., 1963. Les calpionelles dans les couches de passage Jurassique-Crétacé de la fosse vocontienne. Trav. Lab. Geol. Fac. Sci. Grenoble, 39:25-82.

1964. Untersuchungen zur Systematik und Stratigraphie der Calpionellen in den Jura-Kreide-Grenzschichten des Vocontischen Troges. Palaeontographica A, 123:1-57.

1971. Les calpionelles, protozoaires planctoniques des mers mésogéennes de l'époque secondaire. Ann. Guebhard, 47:1-25.

Trejo, M, 1976. Tintínidos mesozoicos de México (taxonomía y datos paleobiológicos). Bol. Asoc. Mex. Geol. Petrol., 27:329-449. 1980. Distribución estratigráfica de los Tintínidos mesozoicos mexicanos. Rev. Inst. Mex. Pet., 12:4-13.

Date of Initial Receipt: April 30, 1982 

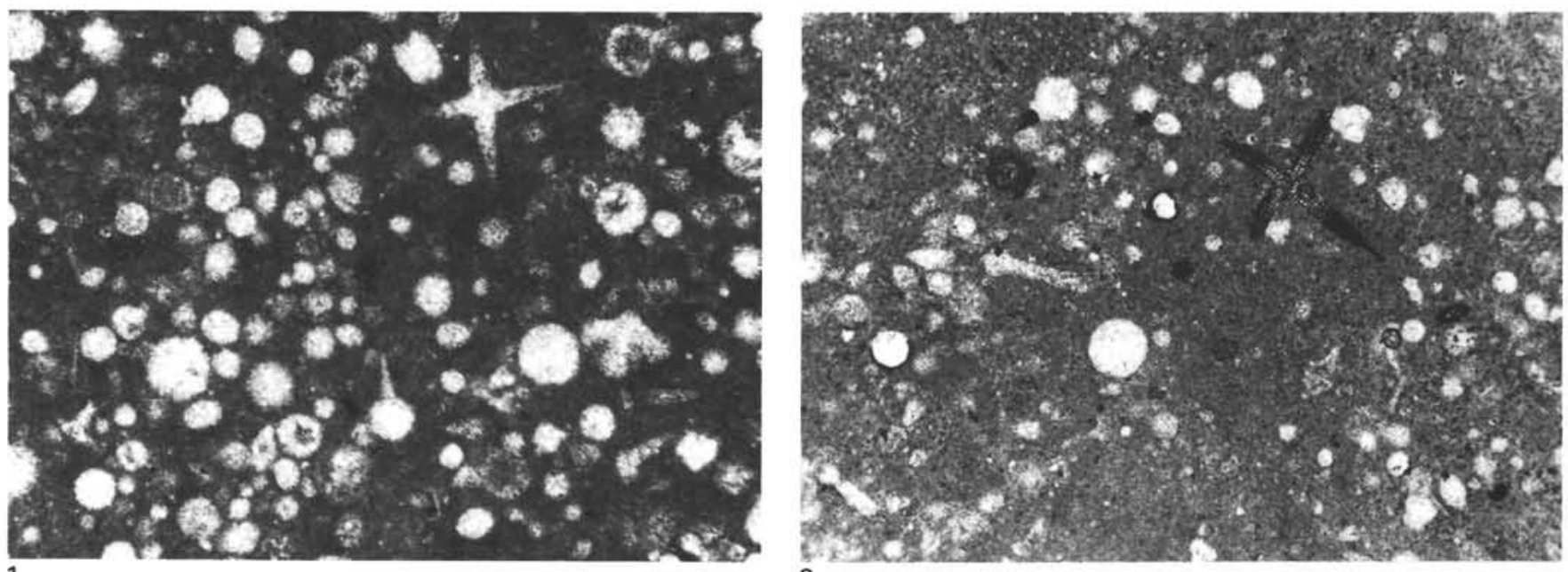

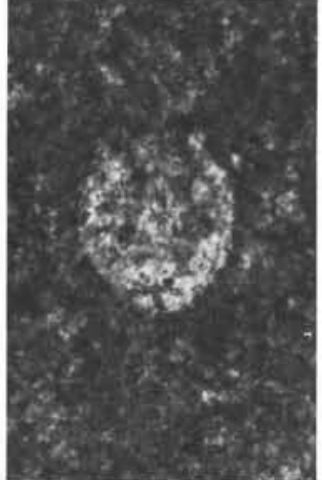

3

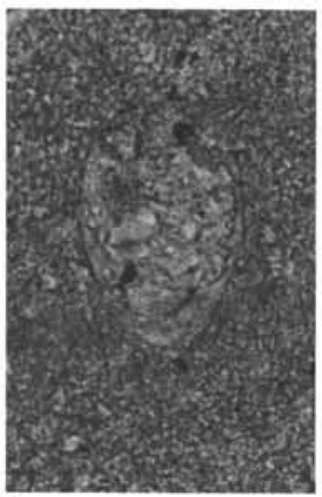

8

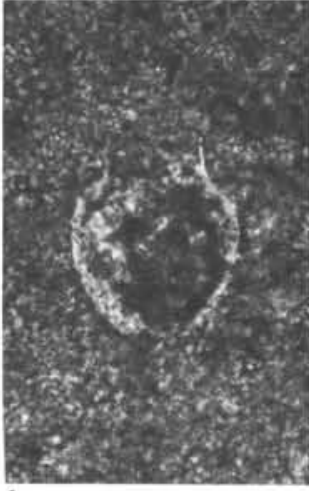

4

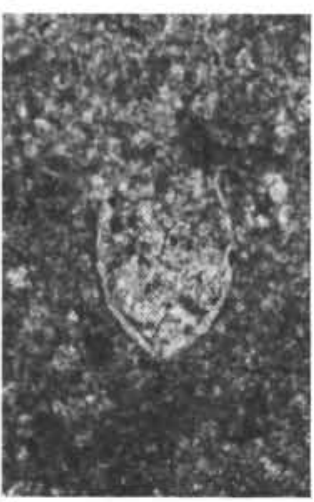

9

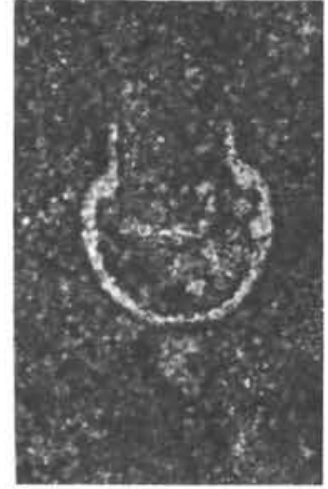

5

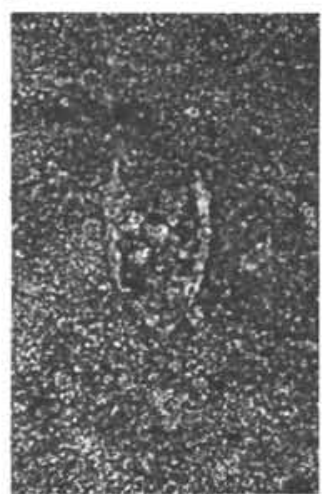

10

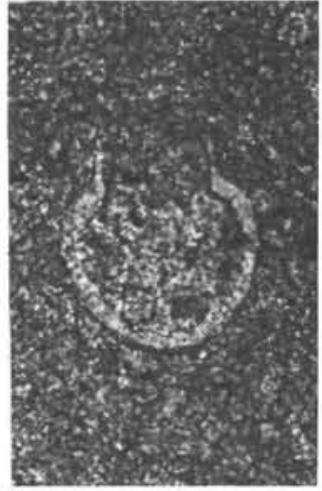

6

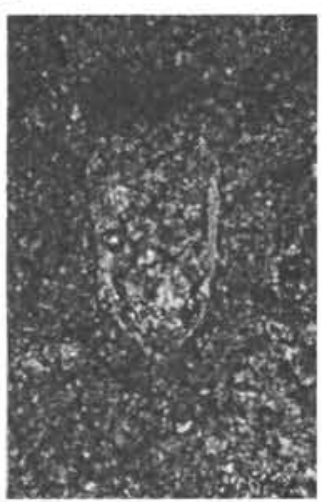

11

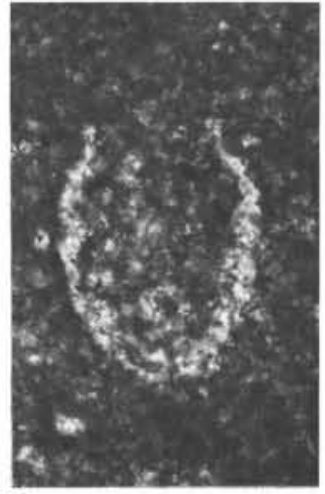

7

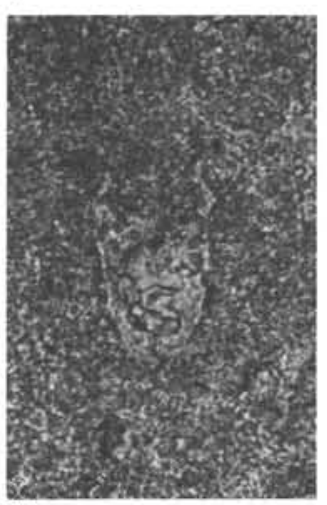

12

Plate 1. 1-2. Typical microfacies of the lowermost Blake-Bahama Formation-micrites or biomicrites with calcified, sometimes also pyritized, radiolarians (magnified approximately $\times 27$ ), (1) Sample $534 \mathrm{~A}-71-3,109-110 \mathrm{~cm}$. (2) Sample $534 \mathrm{~A}-84-3,0-2 \mathrm{~cm}$. 3-12. Calpionellids from the lowermost Blake-Bahama Formation, (Figs. 3-5, 8, 10) and from the uppermost Cat Gap Formation (Figs. 6-7, 9, 11-12), all magnified $\times 230$, (3) Sample 534A-89-3, 64-66 cm. (4) Sample 534A-90-2, 36-38 cm. (8) Sample 534A-90-4, 19-20 cm. (5, 10) Sample 534A-91-1, 112-114 cm. (6, 9) Sample 534A-92-2, 99-101 cm. (7, 11) Sample 534A-93-1, 112-114 cm. (12) Sample 534A-93-1, 129-130 cm. (3-7) Calpionella alpina Lorenz (Fig. 7 shows a rather tangential section of the large form characteristic of Zone A); (8-9) Tintinnopsella carpathica (Murgeanu and Filipescu) (these figures are relatively small forms typical of Zone B); (10) Crassicollaria parvula Remane; (11-12) Crassicollaria intermedia (Durand Delga). 